\title{
PENERAPAN METODE PERAMALAN (FORECASTING) PADA PERMINTAAN ATAP di PT X
}

\author{
Anna Lusiana ${ }^{1)}$, Popy Yuliarty ${ }^{2)}$ \\ 1,2) Prodi Teknik Industri, Universitas Mercu Buana, Jl.Meruya Selatan No.1 Kembangan Jakbar \\ Annalusiana19@gmail.com
}

\begin{abstract}
Abstrak. PT. X merupakan anak perusahaan dari PT. X salah satu perusahaan ternama di Indonesia yang telah berdiri sejak tahun 2013 dan bergerak sebagai distributor ekslusif bagi produk-produk bahan bangunan yang diproduksi oleh perusahaan induk seperti produk atap $\mathrm{H}$, dan beberapa bahan bangunan lainnya serta produk bahan bangunan impor dari negara di kawasan Asia dan Eropa. Tujuan dari penelitian ini yaitu menentukan tiga metode peramalan yang dapat digunakan berdasarkan pola grafik peramalan data historis, menentukan metode peramalan yang tepat dengan tingkat kesalahan paling terkecil berdasarkan ketiga metode tersebut pada permintaan produk Atap H di PT. XYZ. Hasil penelitian yang didapatkan yaitu didapatkan grafik peramalan yang memiliki pola horizontal dikarenakan fluktuasi nilai berada disekitar rata-rata maka perhitungan peramalan permintaan beserta tingkat kesalahannya diketahui bahwa terdapat tiga metode yang digunakan yaitu; Metode Exponential, Exponential Smoothing dengan $\alpha=0,1$ dan Exponential Smoothing dengan $\alpha=0,2$ Sehingga Metode yang paling tepat digunakan dalam menganalisis data dengan memiliki tingkat kesalahan yang paling terkecil dari ketiga metode yang digunakan pada produk Atap H untuk ramalan Januari 2019 yaitu menggunakan Metode Exponential Smoothing dengan $\alpha=0,2$ dengan nilai MAPE yakni 32,67; MAD yakni 286.023,31; MSE yakni 118.336.236.635,27; dan MFE yakni 286.023,31.
\end{abstract}

Kata Kunci: Peramalan Permintaan, Metode Exponential, Metode Exponential Smoothing.

\section{PENDAHULUAN}

Beberapa tahun terakhir ini, pembangunan di Indonesia dinilai sedang mengalami perkembangan. Hal ini memberi dampak positif bagi perusahaan-perusahaan yang bergerak dibidang produksi bahan bangunan. PT. X merupakan anak perusahaan dari PT. A yang telah berdiri sejak tahun 2013 dan merupakan bagian dari grup perseroan terbesar. PT. X Sendiri bergerak sebagai distributor ekslusif bagi produk-produk bahan bangunan yang diproduksi oleh PT. A. PT. X, sangat mempertahankan kualitas dalam memberikan kepercayaan kepada customer. Hal ini didukung dengan sudah tersedianya ISO 9001 yang berkaitan dengan efektifitas penjaminan mutu. Untuk dapat memenuhi permintaan terhadap pesanan bahan-bahan bangunan maka diperlukannya suatu metode perhitungan peramalan yang tepat, yaitu dimana jumlah barang yang tersedia akan diprediksi berdasarkan permintaan bahan bangunan pada satu tahun terakhir.

\section{Pengertian Peramalan}

Menurut Kushartini dan Almahdy (2016), Peramalan adalah proses untuk memperkirakan berapa kebutuhan dimasa datang yang meliputi kebutuhan dalam ukuran kuantitas, kualitas, waktu dan lokasi yang dibutuhkan dalam rangka memenuhi permintaan barang atau jasa. Peramalan merupakan suatu kegiatan memperkirakan atau memprediksikan kejadian dimasa yang akan datang tentunya dengan bantuan penyusunan rencana terlebih dahulu, dimana rencana ini dibuat berdasarkan kapasitas dan kemampuan permintaan/produksi yang telah dilakukan di perusahaan (Sofyan, 2013).

\section{Jenis Pola Peramalan}

Berikut adalah jenis-jenis pola peramalan yang daapat dilihat pada gambar 1 

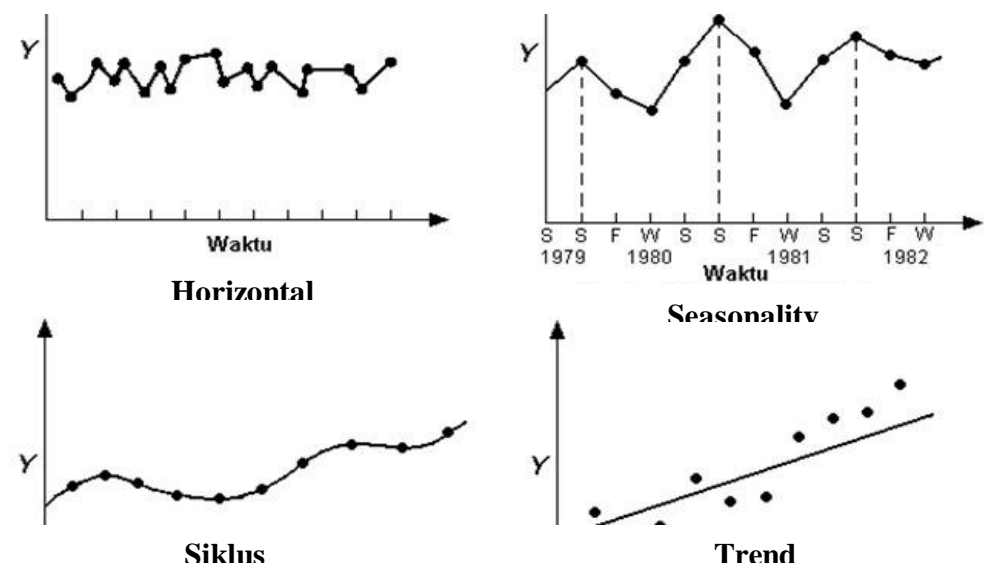

Gambar 1 Jenis Pola Peramalan

Ada beberapa Pola Data (Seto, 2016) :

1) Trend $(\mathrm{T})$, terjadi bila ada kenaikan atau penurunan dari data secara gradual dari gerakan datanya dalam kurun waktu panjang.

2) Seasonality (S) pola musiman terjadi bila pola datanya berulang sesudah suatu periode tertentu: hari, mingguan, bulanan, triwulan dan tahun.

3) Cycles (C), Siklus adalah suatu pola data yang terjadinya setiap beberapa tahun, biasanya dipengaruhi oleh fluktuasi ekonomi jangka panjang berkaitan dengan siklus bisnis.

4) Horizontal $(\mathrm{H}) /$ Stasioner, terjadi bila nilai data berfluktuasi di sekitar nilai rata-rata yang tetap, stabil atau disebut stasioner terhadap nilai rata-ratanya.

Berikut adalah klasisfikasi Metode Peramalan yang dapat digunakan berdasarkan pola datanya pada tabel 1

Tabel 1 Klasifikasi Metode Peramalan

\begin{tabular}{|c|c|c|c|c|}
\hline \multirow{2}{*}{ Metode Peramalan } & \multirow{2}{*}{ Pola Data } & \multirow{2}{*}{ Horizon Waktu } & \multicolumn{2}{|c|}{ Kebutuhan Data Minimal } \\
\hline & & & Nonseasonal & Seasonal \\
\hline \multirow{3}{*}{ Naive } & Stasioner & \multirow{3}{*}{ Sangat Pendek } & \multirow{3}{*}{1 atau 2} & \multirow[t]{3}{*}{ 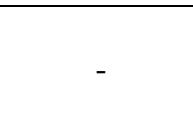 } \\
\hline & Trend & & & \\
\hline & Cyclical & & & \\
\hline Moving Average & Stasioner & Sangat Pendek & Jumlah Periode & - \\
\hline \multirow{5}{*}{$\begin{array}{l}\text { Exponential Smoothing } \\
\text { - simple } \\
\text { - Adaptive Response } \\
\text { - Holt's } \\
\text { - Winter's } \\
\text { - Bass Model }\end{array}$} & Stasioner & Pendek & $5-10$ & \\
\hline & Stasioner & Pendek & $10-15$ & \\
\hline & Linier Trend & Pendek ke Menengah & $10-15$ & \\
\hline & $\begin{array}{l}\text { Trend and } \\
\text { Seasonality }\end{array}$ & Pendek ke Menengah & - & $\begin{array}{l}\text { Min. } 4-5 \text { per } \\
\text { season }\end{array}$ \\
\hline & S-Curve & Menengah ke Tinggi & Kecil, 3-10 & \\
\hline \multirow{2}{*}{$\begin{array}{l}\text { Regressive Base } \\
\text { - Trend } \\
\text { - Causal }\end{array}$} & $\begin{array}{c}\text { Trend, } \\
\text { with/without } \\
\text { Seasonality }\end{array}$ & Menengah & Min. 10 & $\begin{array}{l}\text { Min. } 4-5 \text { per } \\
\text { season }\end{array}$ \\
\hline & $\begin{array}{c}\text { Semua data } \\
\text { pola }\end{array}$ & Pendek, Menengah dan Tinggi & \multicolumn{2}{|c|}{ Min. 10} \\
\hline $\begin{array}{l}\text { Time Series } \\
\text { Decomposition }\end{array}$ & $\begin{array}{l}\text { Trend, } \\
\text { Seasonal, } \\
\text { Cylical }\end{array}$ & Pendek, Menengah dan Tinggi & - & 2 Peaks \\
\hline ARIMA & Stasioner & Pendek, Menengah dan Tinggi & Min. 50 & - \\
\hline
\end{tabular}


Macaam-macam Metode Time-Series Metode time series berhubungan dengan nilai-nilai suatu variabel yang diatur secara priodik sepanjang waktu dimana perkiraan permintaan diproyeksikan, misalnya mingguan, bulanan, kuartalan dan tahunan. Metode time series dibagi menjadi 5 metode yaitu (Sofyan, 2013) :

1) Metode Smoothing, digunakan untuk mengatur data masa lalu sesuai dengan musiman data yang terjadi, dengan cara merata-ratakan sederetan data hingga memiliki jarak dan jumlah data yang cenderung/ hampir seimbang.

- Moving Average, terdiri dari:

a) Simple Moving Average (Rata-rata Bergerak Sederhana). Merupakan metode peramalan yang menggunakan rata-rata dari sejmlah (n) data terkini untuk meramalkan periode mendatang. Dengan menggunakan metode ratarata bergerak ini, deret berkala dari data asli diubah menjadi deret data rata-rata bergerak yang lebih mulus dan tidak terlalau tergantung pada osilasi sehingga lebih memungkinkan untuk menunjukkan trend dasar atau siklus dalam pola data sepanjang waktu. Berikut adalah Model dari ratarata bergerak sederhana antara lain (Rosdiani, 2018) dapat dilihat pada persamaan berikut.

$\overline{M_{t}}=Y_{t+1}=$

$\frac{\left(Y_{1}+Y_{1-1}+Y_{1-2}+\cdots+Y_{1-n-1)}\right)}{n}$

Keterangan :

$\mathrm{M}_{\mathrm{t}}=$ Rata-rata bergerak pada periode $\mathrm{t}$

$\mathrm{Y}_{\mathrm{t}+1}=$ Nilai ramalan perode berikutnya

$\mathrm{Y}_{\mathrm{t}}=$ Jumlah data dalam rata-rata bergerak

b) Weighted Moving Average (Rata-rata Bergerak Tertimbang)

Metode perhitungannya sama dengan rata-rata bergerak sederhana hanya diberi koefisien penimbang. Penetapan besar koefisien penimbang dapat dilakukan secara sembarang, tetapi pada ummnya besaran koefisien penimbang periode terakhir dari data historis adalah dua kali daripada koefisien penimbang periode sebelumnya (Tampubolon,

\section{(Runtun Waktu)}

2018). Berikut adalah Model dari ratarata bergerak tertimbang menurut Sofyan (2013) adalah sebagai berikut:

$$
\begin{aligned}
Y^{\prime}{ }_{t}=W_{1} A_{t-1} & +W_{2} A_{t-2}+\cdots \\
& +W_{n} A_{t-n}
\end{aligned}
$$

Keterangan :

$\mathrm{A}=$ Permintaan aktual pada periode $\mathrm{t}$

$\mathrm{W}_{1}=$ Bobot $(0 \leq \mathrm{Wt} \leq 1)$ yang diberikan pada periode $\mathrm{t}-1 \mathrm{dsb}$

$\mathrm{n}=$ Jumlah periode

\section{- Exponential Smoothing}

a) Single Exponential Smoothing. Single Exponential Smoothing digunakan untuk jarak pendek perkiraan. Model mengasumsikan bahwa data berfluktuasi sekitar rata-rata yang cukup stabil (Rosdiani, 2018). Berikut adalah Model dari single exponential smopthing menurut Sofyan (2013) adalah sebagai berikut.

$Y^{\prime}{ }_{t+1}=\alpha \cdot T_{t}+(1-\alpha) \cdot Y^{\prime}{ }_{t}$

Keterangan :

$\mathrm{T}_{\mathrm{t}}=$ data permintaan pada periode $\mathrm{t}$

$\alpha=$ faktor/ konstanta pemulusan

$\mathrm{Y}^{\prime}{ }_{\mathrm{t}+1}=$ peramalan untuk periode $\mathrm{t}$

\section{b) Double Exponential Smoothing}

Menrut Sofyan (2013), Double Exponential Smoothing dibagi menjadi dua yaitu dengan Satu parameter dan Dua parameter, seperti berikut:

- Satu Parmeter (Brown's linear method), merupakan metode yang hampir sama dengan metode linear moving average dan sesuaikan yaitu dengan menambahkan satu parameter.

$S^{\prime}{ }_{t}=\alpha X_{t}+(1-\alpha) S^{\prime}{ }_{t-1}$

$S^{\prime \prime}{ }_{t}=\alpha X_{t}+(1-\alpha) S^{\prime \prime}{ }_{t-1}$

Keterangan :

$\mathrm{S}_{\mathrm{t}}$ merupakan Single exponential smoothing

$\mathrm{S}_{\mathrm{t}}$ merupakan Double exponential smoothing

$$
\begin{aligned}
& a_{t}=S^{\prime}{ }_{t}+\left(S^{\prime}{ }_{t}-S^{\prime \prime}{ }_{t}\right) \\
& a_{t}=2 S^{\prime}{ }_{t}-S^{\prime \prime}{ }_{t} \\
& b_{t}=\frac{\alpha}{1-\alpha}\left(S^{\prime}{ }_{t}-S^{\prime \prime}{ }_{t}\right) \\
& Y^{\prime}{ }_{t+m}=a_{t} \cdot b_{t} \cdot m
\end{aligned}
$$


- Dua Parameter (Holt's methode), merupakan metode double exponential smoothing untuk time series dengan trend linier. Terdapat konstanta yaitu $\alpha$ dan $\beta$.

$S_{t}=\alpha D_{t}+(1-\alpha)\left(S_{t-1}+G_{t-1}\right)$

$G_{t}=\beta\left(S_{t}-S_{t-1}\right)+(1-\beta) G_{t-1}$

$Y^{\prime}{ }_{t+m}=S_{t} \cdot G_{t} \cdot m$

Keterangan :

$\mathrm{S}_{\mathrm{t}}=$ intercept pada waktu $\mathrm{t}$

$\mathrm{G}_{\mathrm{t}}=$ Slope pada waktu $\mathrm{t}$

$\mathrm{Y}^{\prime}{ }_{\mathrm{t}+\mathrm{m}}=$ Ramalan untuk $\mathrm{m}$ periode kedepan

2) Metode Proyeksi Kencendrungan dengan Regresi, merupakan metode perhitungan peramalan berdasarkan garis kecendrungan, sehingga dapat diproyeksikan hal-hal yang akan diteliti pada masa yang akan datang. Metode regresi terbagi atas beberapa metode, antara lain (Sofyan, 2013):

- Konstan

$$
\begin{aligned}
& Y^{\prime}=a \\
& a=\frac{\sum X}{n}
\end{aligned}
$$

Keterangan :

$\mathrm{Y}^{\prime}=$ nilai peramalan pada periode $\mathrm{t}$

$\mathrm{n}=$ jumlah periode

- Linier

$$
Y^{\prime}=\frac{\sum Y(t)-b \sum t}{n}+\frac{n \sum t y-\sum(t) \sum(y)}{n-\sum t^{2}-\left(\sum t\right)^{2}}
$$

- Kuadratis

$$
Y^{\prime}=a+b t+c t^{2}
$$

Dimana:

$$
\begin{aligned}
a & =\frac{\sum Y-b \sum t-c \sum t^{2}}{n} \\
b & =\frac{\partial \delta-\theta \alpha}{\partial \beta-\alpha^{2}} \\
c & =\frac{\theta-b \alpha}{\gamma} \\
\gamma & =\left(\sum t^{2}\right)^{2}-n \sum t^{4} \\
\delta & =\sum t \sum Y-n \sum t Y \\
\theta & =\sum t^{2} \sum Y-n \sum t^{2} Y \\
\alpha & =\sum t \sum t^{2}-n \sum t^{3} \\
\beta & =\left(\sum t\right)^{2}-n \sum t^{2}
\end{aligned}
$$

Pola data dalam kuadratis dapat digambarkan pada gambar 2 .

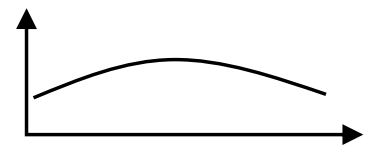

Gambar 2. Pola Data Kuadratis
3) Metode Musiman (seasonal), metode ini sangat dipengaruhi oleh faktor musiman, dimana menggambarkan pola penjualan yang berulang setiap periode (Sofyan, 2013).

4) Metode Trend, Metode ini terjadi bila data memiliki kecendrungan untuk naik atau turun terus menerus (Sofyan, 2013). Ada beberapa model trend yang dapat digunakan adalah sebagai berikut:

- Trend Linier

$$
Y^{\prime}=a+b t
$$

Dimana:

Y' $\quad=$ Nilai ramalan pada periode ke-t

$\mathrm{T}=\mathrm{Waktu} /$ periode

$$
b=\frac{n \sum(t Y(t))-\left(\sum Y(t)\right)\left(\sum t\right)}{n \sum t^{2}-\left(\sum t\right)^{2}}
$$$$
a=\frac{\sum Y_{t}-b \sum t}{n}
$$

- Trend Eksponensial

$$
\begin{gathered}
Y^{\prime}=a e^{b t} \\
b=\frac{n \sum t \ln Y_{t}-\sum t \sum \ln Y_{t}}{n \sum t^{2}-\left(\sum t\right)^{2}} \\
\ln a=\frac{\sum \ln Y_{t}-b \sum t}{n}
\end{gathered}
$$

5) Metode Dekomposisi, Merupakan metode peramalan yang ditentukan dengan kombinasi dari fungsi yang ada sehingga metode ini baru dapat digunakan jika didekatkan dengan fungsi linier atau siklis dan kemudian dibagi atas waktu baik dalam kuartalan sementara ataupun berdasarkan pola data yang ada (Sofyan, 2013).

\section{Uji Kesalahan Peramalan}

Uji Kesalahan Peramalan digunakan dengan membandingkan hasil peramalan dengan data aktual. Menurut Sofyan, 2013 makin kecil nilai kesalahan maka makin tinggi tingkat ketelitian peramalan, demikian sebaliknya. Besarnya kesalahan peramalan dapat dihitung dengan menggunakan beberapa metode pwrhitungan yaitu:

MAD (Mean Absolute Deviation) adalah ratarata kesalahan mutlak selama periode tertentu tanpa memperhatikan apakah hasil peramalan lebih besar atau lebih kecil dari kenyataan. MAD mengukur ketepatan ramalan dengan merata-rata kesalahan dugaan (nilai absolut masing-masing kesalahan) serta MAD memberikan bobot yang sama pada setiap nilai selisih peramalan dan aktual dapat dilihat pada persamaan berikut 


$$
M A D=\sum\left|\frac{A_{t}-F_{t}}{n}\right|
$$

1. MSE (Mean Square Error), rata-rata kuadrat kesalahan. Perhitungan eror ini memberikan pinalti pada selisi yang lebih besar dibandingkan selisih yang kecil melalui perhitungan kuadrat dapat dilihat pada persamaan berikut

$$
M S E=\sum \frac{\left(A_{t}-F_{t}\right)^{2}}{n}
$$

$\mathrm{A}_{\mathrm{t}}=$ Permintaan Aktual pada periode- $\mathrm{t}$

$\mathrm{F}_{\mathrm{t}}=$ Peramalan Permintaan pada periode-

$\mathrm{n} \quad=$ Jumlah Periode Permintaan yang terlibat

2. MFE (Mean Forecast Error), perhitungan eror ini dengan menjumlahkan semua kesalahan peramalan selama periode dan membagi dengan jumlah periode. MFE sangat efektif untuk mengetahui apakah suatu hasil peramalan selama periode tertentu terlalu tinggi atau rendah, dapat dilihat pada persamaan berikut

$$
M A D=\sum \frac{\left(A_{t}-F_{t}\right)}{n}
$$

3. MAPE (Mean Absolute Percentage Error), merupakan rata-rata kesalahan mutlak selama periode tertentu yang dikalikan $100 \%$ agar mendapatkan hasil secara persentase dan digunakan jika ukuran variabel yang diramalkan sangat menentukan akurasi peramalan dapat dilihat pada persamaan berikut

$$
M A P E=\left(\frac{100}{n}\right) \sum\left|A_{t}-\frac{F_{t}}{A_{t}}\right|
$$

\section{METODE}

Untuk mencapai tujuan yang ingin dicapai yaitu mengetahui peramalan permintaan pada produk Atap $\mathrm{H}$, maka diperlukan kegiatan observasi dan wawancara. Kegiatan wawancara dimaksudkan untuk memperoleh informasi yang ditujukan kepada setiap pihak yang dinilai berperan langsung pada proses logistik pada PT. X. Selanjutnya dilakukan pencatatan data yang menunjang pengumpulan informasi pada peramalan permintaan barang, baik berupa data primer maupun data sekunder. Berikut adalah langkah-langkah dalam melakukan peramalan yaitu dapat dilihat pada gambar 3 .

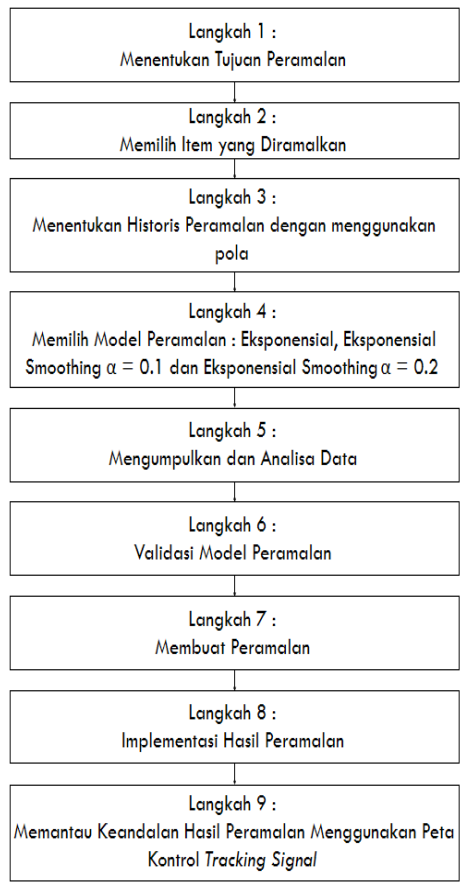

Gambar 3. Step Peramalan

\section{HASIL DAN PEMBAHASAN \\ Penentuan Metode Peramalan dengan Menggunakan Pola}

Langkah awal yang harus dilakukan dalam meramalkan permintaan pada periode kedepan yaitu dengan mengumpulkan datadata historis. Berikut adalah data permintaan pada tahun 2018 dapat dilihat pada tabel 2 .

Tabel 2. Data Permintaan Tahun 2018

\begin{tabular}{|c|c|}
\hline Bulan & Jumlah \\
\hline Januari & 959.288 \\
\hline Februari & 848.601 \\
\hline Maret & 922.392 \\
\hline April & 885.497 \\
\hline Mei & 885.497 \\
\hline Juni & 701.018 \\
\hline Juli & 959.288 \\
\hline Agustus & 922.392 \\
\hline September & 885.497 \\
\hline Oktober & 996.184 \\
\hline November & 996.184 \\
\hline Desember & 996.184 \\
\hline TOTAL & $\mathbf{1 0 . 9 5 8 . 0 2 2}$ \\
\hline
\end{tabular}


Berikut adalah grafik jumlah penjualan berdasarkan data permintaan pada tahun 2018 dapat dilihat pada gambar 4.

Dari hasil grafik penjualan dapat diidentifikasikan bahwa pola perubahan permintaanya adalah Pola Horizontal. Dikarenakan terjadi naik dan turunnya pada penjualan Atap $\mathrm{H}$ dengan fluktuasi yang masih berada disekitar rata-rata. Menurut Heriansyah dan Hasibuan (2017), pada data time series yang berbasis waktu, diperlukan pengujian terlebih dahulu sebelum data tersebut diolah dengan uji pola data. Uji pola data adalah menguji apakah dikatakan stasioner atau tidak. Jika pada data terdapat trend, seasonal atau siklis, maka dapat dikatakan data tidak stasioner, begitu juga sebaliknya.

Dengan pola grafik Horizontal maka dapat disimpulkan data bersifat stasioner dan metode yang dapat digunakan untuk menganalisa pola siklus tersebut dengan metode peramalan, Exponential dan Exponential Smoothing dengan $\alpha=0,1$, dan Exponential Smoothing dengan $\alpha=0,2$.

\section{Metode Peramalan Exponential}

Berikut adalah perhitungan peramalan dengan menggunakan Metode Peramalan Exponential yang dapat dilihat pada tabel 3 berikut ini.

Tabel 3 Metode Peramalan Exponential

\begin{tabular}{|c|c|c|c|c|c|}
\hline Bulan & $\mathbf{t}$ & $\mathbf{Y}(\mathbf{t})$ & $\mathbf{l n}$. Y (t) & $\mathbf{t}$. $\mathbf{l n} \mathbf{Y}(\mathbf{t})$ & $\mathbf{t}^{\mathbf{2}}$ \\
\hline Januari & 1 & 959.288 & 13,77 & 13,77 & 1 \\
\hline Februari & 2 & 848.601 & 13,65 & 27,30 & 4 \\
\hline Maret & 3 & 922.392 & 13,73 & 41,20 & 9 \\
\hline April & 4 & 885.497 & 13,69 & 54,77 & 16 \\
\hline Mei & 5 & 885.497 & 13,69 & 68,47 & 25 \\
\hline Juni & 6 & 701.018 & 13,46 & 80,76 & 36 \\
\hline Juli & 7 & 959.288 & 13,77 & 96,42 & 49 \\
\hline Agustus & 8 & 922.392 & 13,73 & 109,88 & 64 \\
\hline September & 9 & 885.497 & 13,69 & 123,24 & 81 \\
\hline Oktober & 10 & 996.184 & 13,81 & 128,12 & 100 \\
\hline November & 11 & 996.184 & 13,81 & 151,93 & 121 \\
\hline Desember & 12 & 996.184 & 13,81 & 165,74 & 144 \\
\hline Total Jumlah & $\mathbf{7 8}$ & $\mathbf{1 0 . 9 5 8 . 0 2 2}$ & $\mathbf{1 6 4 , 6 4}$ & $\mathbf{1 . 0 7 1 , 6}$ & $\mathbf{6 5 0}$ \\
\hline
\end{tabular}

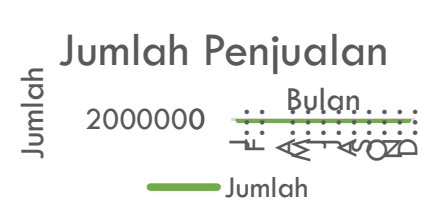

Gambar 4 Grafik Data Permintaan

$$
\begin{aligned}
\boldsymbol{b} & =\frac{\boldsymbol{n} \cdot \sum \boldsymbol{t} \cdot \ln \boldsymbol{Y}(\boldsymbol{t})-\left(\sum t\right) \cdot \sum \ln \boldsymbol{y}(\boldsymbol{t})}{\boldsymbol{n} \cdot \sum \boldsymbol{t}^{2}-\left(\sum t\right)^{2}} \\
b & =\frac{12(1.071,6)-78(164,64)}{12(650)-(78)^{2}} \\
b & =\frac{12.859,2-12.841,92}{7.800-6.084} \\
b & =\frac{17,28}{1.716} \\
b & =10,07
\end{aligned}
$$

$$
\begin{aligned}
& \boldsymbol{a}=\frac{\sum \ln Y(t)}{\boldsymbol{n}}-\frac{\boldsymbol{b} \cdot \Sigma \boldsymbol{t}}{\boldsymbol{n}} \\
& a=\frac{164,64}{12}-\frac{10,07(78)}{12} \\
& a=13,72-65,45 \\
& a=-51,73
\end{aligned}
$$

Sehingga persamaan regresi peramalan permintaannya adalah :

Periode 1:

$$
\begin{aligned}
& \boldsymbol{d}^{\prime}=\boldsymbol{Y}^{\prime}(\boldsymbol{t})=\boldsymbol{a} \cdot \boldsymbol{e}^{\boldsymbol{b}} \cdot \boldsymbol{t} \\
& d^{\prime}=Y^{\prime}(t)=-51,73\left(2,718^{10,07}\right) 1 \\
& d^{\prime}=Y^{\prime}(t)=-51,73(23,60) 1 \\
& d^{\prime}=Y^{\prime}(t)=-1.220,82
\end{aligned}
$$

Dst,

Berikut adalah perhitungan peramalan Exponential setelah persamaan regresi dapat dilihat pada tabel 4 
Tabel 4 Metode Peramalan Exponential Setelah Persamaan Regresi

\begin{tabular}{|c|c|c|c|c|c|c|c|c|}
\hline Bulan & $\mathbf{t}$ & $\mathbf{Y}(\mathbf{t})=\mathbf{d}$ & $Y^{\prime}(t)=d^{\prime}$ & (d-d') & |d-d'| & $\left(d-d^{\prime}\right)^{2}$ & $\left(d-d^{\prime}\right)^{2} / n$ & $\begin{array}{c}\mid d- \\
d^{\prime} \mid / d * 100\end{array}$ \\
\hline Januari & 1 & 959.288 & $-1.220 .771,73$ & $\begin{array}{c}2.180 .059,7 \\
3 \\
\end{array}$ & $\begin{array}{c}2.180 .059 \\
73\end{array}$ & $\begin{array}{c}4.752 .660 .432 . \\
265,41\end{array}$ & $181.671,64$ & 227,26 \\
\hline Februari & 2 & 848.601 & $-2.441 .543,46$ & $\begin{array}{c}3.290 .144,4 \\
6 \\
\end{array}$ & $\begin{array}{l}3.290 .144 \\
46\end{array}$ & $\begin{array}{c}10.825 .050 .585 \\
.470,40\end{array}$ & $274.178,70$ & 387,71 \\
\hline Maret & 3 & 922.392 & -3.662 .315 .19 & $4.584 .707,19$ & $4.584 .707,19$ & $\begin{array}{c}21.019 .540 .055 .24 \\
6,80\end{array}$ & $382.058,93$ & 497,04 \\
\hline April & 4 & 885.497 & $-4.883 .086,93$ & $5.768 .583,93$ & $5.768 .583,92$ & $\begin{array}{c}33.276 .560 .504 .50 \\
5,80\end{array}$ & $480.715,33$ & 651,45 \\
\hline Mei & 5 & 885.497 & $-6.103 .858,66$ & $6.989 .355,66$ & $6.989 .355,66$ & $\begin{array}{c}48.851 .092 .496 .72 \\
8,70\end{array}$ & $582.446,30$ & 789,31 \\
\hline Juni & 6 & 701.018 & $-7.324 .630,39$ & $8.025 .648,39$ & $8.025 .648,39$ & $\begin{array}{c}64.411 .032 .049 .66 \\
7,70\end{array}$ & $668.804,03$ & $1.144,85$ \\
\hline Juli & 7 & 959.288 & $-8.545 .402,12$ & $\begin{array}{l}9.504 .690,1 \\
2 \\
\end{array}$ & $\begin{array}{l}9.504 .690 \\
12\end{array}$ & $\begin{array}{c}90.339 .134 .267 \\
.123,60\end{array}$ & $792.057,51$ & 990,81 \\
\hline Agustus & 8 & 922.392 & $-9.766 .173,85$ & $\begin{array}{l}1.068 .8565 \\
85\end{array}$ & $\begin{array}{c}10.688 .565 \\
, 85\end{array}$ & $\begin{array}{c}114.245 .439 .94 \\
7.342,00\end{array}$ & $890.713,82$ & $1.158,79$ \\
\hline September & 9 & 885.497 & $-10.986 .945,58$ & $\begin{array}{c}11.872 .442, \\
58\end{array}$ & $\begin{array}{c}11.872 .442 \\
.58\end{array}$ & $\begin{array}{c}140.954 .892 .86 \\
7.016,00\end{array}$ & $989.370,21$ & $1.340,76$ \\
\hline Oktober & 10 & 996.184 & $-12.207 .717,31$ & $\begin{array}{l}13.203 .901 \\
31\end{array}$ & $\begin{array}{c}13.203 .901 \\
, 31\end{array}$ & $\begin{array}{c}174.343 .009 .89 \\
7.348,00\end{array}$ & $\begin{array}{c}1.100 .325,1 \\
0\end{array}$ & $1.325,45$ \\
\hline November & 11 & 996.184 & $13.428 .489,04$ & $\begin{array}{c}14.424 .673 \\
04\end{array}$ & $\begin{array}{c}14.424 .673 \\
, 04\end{array}$ & $\begin{array}{c}208.071 .192 .45 \\
1.664,00\end{array}$ & $\begin{array}{c}1.202 .056,0 \\
9\end{array}$ & $1.447,99$ \\
\hline Desember & 12 & 996.184 & $14.649 .260,78$ & $\begin{array}{c}15.645 .444, \\
78\end{array}$ & $\begin{array}{c}15.645 .444 \\
, 78\end{array}$ & $\begin{array}{c}244.779 .942 .24 \\
6.120,00\end{array}$ & $\begin{array}{c}1.303 .787,0 \\
6\end{array}$ & $1.570,54$ \\
\hline $\begin{array}{c}\text { Total } \\
\text { Jumlah }\end{array}$ & 78 & $\begin{array}{c}10.958 .0 \\
22\end{array}$ & $-95.220 .195,05$ & $\begin{array}{c}\text { 106.178.217 } \\
, 05\end{array}$ & $\begin{array}{c}106.178 .21 \\
7,05\end{array}$ & $\begin{array}{c}1.155 .869 .547 \\
800.500,00\end{array}$ & $\begin{array}{c}\text { 8.848.184,7 } \\
5\end{array}$ & $11.531,98$ \\
\hline
\end{tabular}

Metode Peramalan Exponential

Smoothing $\alpha=0,1$

Berikut Metode peramalan Exponential

Smoothing dengan persamaan:

$F_{t}=F_{t-1}+\alpha\left(A_{t-1}-F_{t-1}\right)$

dimana,

Berikut adalah perhitungan peramalan Exponential Smoothing dengan $\alpha=0,1$ dapat dilihat pada tabel 5 .

Tabel 5 Metode Peramalan Exponential Smoothing dengan $\alpha=0,1$

\begin{tabular}{|c|c|c|c|c|c|c|c|c|}
\hline Bulan & $\mathbf{t}$ & $\mathbf{Y}(\mathbf{t})=\mathbf{d}$ & $Y^{\prime}(t)=d^{\prime}$ & (d-d') & |d-d'| & $\left(d-d^{\prime}\right)^{2}$ & $\left(d-d^{\prime}\right)^{2} / n$ & $\begin{array}{c}\mid d- \\
d^{\prime} \mid / d * 1 \\
00\end{array}$ \\
\hline Januari & 1 & 959.288 & - & - & - & - & - & - \\
\hline Februari & 2 & 848.601 & $95.928,80$ & $752.672,20$ & $752.672,20$ & $\begin{array}{c}566.515 .44 \\
0.652,84\end{array}$ & $\begin{array}{c}47.209 .62 \\
0.054,40\end{array}$ & 88.70 \\
\hline Maret & 3 & 922.392 & $84.860,10$ & $837.531,90$ & 837.53190 & $\begin{array}{c}701.459 .68 \\
3.517,61\end{array}$ & $\begin{array}{c}58.454 .97 \\
3.626,47\end{array}$ & 90.80 \\
\hline April & 4 & 885.497 & $92.239,20$ & $793.257,80$ & $793.257,80$ & $\begin{array}{c}629.257 .93 \\
7.260,84\end{array}$ & $\begin{array}{c}52.438 .16 \\
1.438,40\end{array}$ & 89.58 \\
\hline Mei & 5 & 885.497 & $88.549,70$ & $796.947,30$ & $796.947,30$ & $\begin{array}{c}635.124 .99 \\
8.977,29\end{array}$ & $\begin{array}{c}52.927 .08 \\
3.248,11\end{array}$ & \\
\hline Juni & 6 & 701.018 & $88.549,70$ & $612.468,30$ & $612.468,30$ & $\begin{array}{c}375.117 .41 \\
8.504,89\end{array}$ & $\begin{array}{c}31.259 .78 \\
4.875,41\end{array}$ & \\
\hline Juli & 7 & 959.288 & $70.101,80$ & $889.186,20$ & $889.186,20$ & $\begin{array}{c}790.652 .09 \\
8.270,44\end{array}$ & $\begin{array}{c}65.887 .67 \\
4.855,87\end{array}$ & \\
\hline Agustus & 8 & 922.392 & $95.928,80$ & $826.463,20$ & $826.463,20$ & $\begin{array}{c}68.3041 .42 \\
0.954,24\end{array}$ & $\begin{array}{c}56.920 .11 \\
8.412,85\end{array}$ & \\
\hline
\end{tabular}

Pada periode pertama nilai d' atau Y'(t) adalah 0

$\mathrm{F}_{\mathrm{t}-1}=\mathrm{d}^{\prime}$ atau $\mathrm{Y}^{\prime}(\mathrm{t})$ pada periode atau bulan sebelumnya

$\mathrm{A}_{\mathrm{t}-1}=\mathrm{d}$ atau $\mathrm{Y}(\mathrm{t})$ pada periode atau bulan sebelumnya 


\begin{tabular}{|c|c|c|c|c|c|c|c|c|}
\hline \hline September & 9 & 885.497 & $92.239,20$ & $793.257,80$ & $793.257,80$ & $\begin{array}{c}629.257 .93 \\
7.260,84\end{array}$ & $\begin{array}{c}52.438 .16 \\
1.438,40\end{array}$ & \\
\hline Oktober & 10 & 996.184 & $88.549,70$ & $907.634,30$ & $907.634,30$ & $\begin{array}{c}823.800 .02 \\
2.536,49\end{array}$ & $\begin{array}{c}68.650 .00 \\
1.878,04\end{array}$ & \\
\hline November & 11 & 996.184 & $99.618,40$ & $896.565,60$ & $896.565,60$ & $\begin{array}{c}803.829 .87 \\
5.103,36\end{array}$ & $\begin{array}{c}66.985 .82 \\
2.925,28\end{array}$ & \\
\hline Desember & 12 & 996.184 & $99.618,40$ & $896.565,60$ & $896.565,60$ & $\begin{array}{c}803.829 .87 \\
5.103,36\end{array}$ & $\begin{array}{c}66.985 .82 \\
2.925,28\end{array}$ & \\
\hline $\begin{array}{c}\text { Total } \\
\text { Jumlah }\end{array}$ & $\mathbf{7 8}$ & $\mathbf{1 0 . 9 5 8 . 0 2 2}$ & $\mathbf{9 9 6 . 1 8 3 , 8 0}$ & $\mathbf{9 . 0 0 2 . 5 5 0 , 2 0}$ & $\begin{array}{c}\mathbf{9 . 0 0 2 . 5 5 0 , 2} \\
\mathbf{0}\end{array}$ & $\begin{array}{c}\mathbf{7 . 4 4 1 . 8 8 6 . 7} \\
\mathbf{0 8 . 1 4 2 , 2 0}\end{array}$ & $\begin{array}{c}\mathbf{6 2 0 . 1 5 7 . 2} \\
\mathbf{2 5 . 6 7 8 , 5 2}\end{array}$ & \\
\hline
\end{tabular}

\section{Metode Peramalan Exponential Smoothing $\alpha=0,2$}

Berikut adalah perhitungan peramalan Exponential Smoothing dengan $\alpha=0,1$ dapat dilihat pada tabel 6

Tabel 6 Metode Peramalan Exponential Smoothing dengan $\alpha=0,2$

\begin{tabular}{|c|c|c|c|c|c|c|c|c|}
\hline Bulan & $\mathbf{t}$ & $Y(t)=d$ & $Y^{\prime}(t)=d^{\prime}$ & (d-d') & |d-d'| & $\left(d-d^{\prime}\right)^{2}$ & $\left(d^{-}-d^{\prime}\right)^{2} / \mathbf{n}$ & $\begin{array}{c}\mid d- \\
d^{\prime} \mid / d * 1 \\
00\end{array}$ \\
\hline Januari & 1 & 959.288 & - & - & - & - & - & - \\
\hline Februari & 2 & 848.601 & $191.857,60$ & $656.743,40$ & $656.743,40$ & $\begin{array}{c}431.311 .89 \\
3.443,56\end{array}$ & $\begin{array}{c}35.942 .65 \\
7.786,96\end{array}$ & 77,39 \\
\hline Maret & 3 & 922.392 & $323.206,28$ & $599.185,72$ & $599.185,72$ & $\begin{array}{c}359.023 .52 \\
7.051,92 \\
\end{array}$ & $\begin{array}{c}29.918 .62 \\
7.254,33 \\
\end{array}$ & 64,96 \\
\hline April & 4 & 885.497 & $443.043,42$ & $442.453,58$ & $442.453,58$ & $\begin{array}{c}195.765 .16 \\
6.915,19 \\
\end{array}$ & $\begin{array}{c}16.313 .76 \\
3.909,60\end{array}$ & 49,97 \\
\hline Mei & 5 & 885.497 & $531.534,14$ & $353.962,86$ & $353.962,86$ & $\begin{array}{c}125.289 .70 \\
6.825,72\end{array}$ & $\begin{array}{c}10.440 .80 \\
8.902,14\end{array}$ & 39,97 \\
\hline Juni & 6 & 701.018 & $602.326,71$ & $98.691,29$ & $98.691,29$ & $\begin{array}{c}9.739 .970 .4 \\
53,42\end{array}$ & $\begin{array}{c}811.664 .2 \\
04,45\end{array}$ & 14,08 \\
\hline Juli & 7 & 959.288 & $622.064,97$ & $337.223,03$ & $337.223,03$ & $\begin{array}{c}113.719 .37 \\
2.577,48\end{array}$ & $\begin{array}{c}9.476 .614 \\
.381,46\end{array}$ & 35,15 \\
\hline Agustus & 8 & 922.392 & $689.509,58$ & $232.882,42$ & $232.882,42$ & $\begin{array}{c}54.234 .223 \\
747,94\end{array}$ & $\begin{array}{c}4.519 .518 \\
.645,66\end{array}$ & 25,25 \\
\hline September & 9 & 885.497 & $736.086,06$ & $149.410,94$ & $149.410,94$ & $\begin{array}{c}22.323 .628 \\
927,04\end{array}$ & $\begin{array}{c}1.860 .302 \\
.410,59 \\
\end{array}$ & 16,87 \\
\hline Oktober & 10 & 996.184 & $765.968,25$ & $230.215,75$ & $230.215,75$ & $\begin{array}{c}52.999 .292 . \\
389,25\end{array}$ & $\begin{array}{c}4.416 .607 \\
.699,10 \\
\end{array}$ & 23,11 \\
\hline November & 11 & 996.184 & $812.011,40$ & $184.172,60$ & $184.172,60$ & $\begin{array}{c}33.919 .547 . \\
129,12\end{array}$ & $\begin{array}{c}2.826 .628 \\
.927,43 \\
\end{array}$ & 18,49 \\
\hline Desember & 12 & 996.184 & $848.845,92$ & $147.338,08$ & $147.338,08$ & $\begin{array}{c}21.708 .510 . \\
162,63 \\
\end{array}$ & $\begin{array}{c}.809 .042 \\
.513,55 \\
\end{array}$ & 14,79 \\
\hline $\begin{array}{c}\text { Total } \\
\text { Jumlah }\end{array}$ & 78 & 10.958.022 & 6.566.454,32 & $343.2279,68$ & $343.2279,68$ & $\begin{array}{c}1.420 .034 .8 \\
39.623,26 \\
\end{array}$ & \begin{tabular}{|l|}
11.833 .62 \\
$3.6635,27$ \\
\end{tabular} & 380,03 \\
\hline
\end{tabular}

\section{Uji Kesalahan Peramalan}

Berikut adalah perhitungan uji kesalahan peramalan pada metode exponential, exponential smoothing $\alpha=0,1$, exponential smoothing $\alpha=0,2$ dapat dilihat pada tabel 7 berikut

Table 7 Uji Kesalahan Peramalan

\begin{tabular}{|c|c|c|c|c|}
\hline Metode Peramalan & MAPE & MAD & MSE & MFE \\
\hline Exponential & 961 & $8.848 .184,75$ & $96.322 .462 .316 .708,30$ & $8.848 .184,75$ \\
\hline $\begin{array}{c}\text { Exponential } \\
\text { Smoothing } \alpha=0,1\end{array}$ & 52,52 & $474.088,67$ & $263.754 .545 .864,38$ & $474.088,67$ \\
\hline $\begin{array}{c}\text { Exponential } \\
\text { Smoothing } \alpha=0,2\end{array}$ & 31,67 & $286.023,31$ & $118.336 .236 .635,27$ & $286.023,31$ \\
\hline
\end{tabular}


Berdasarkan analisa dengan ketiga metode tersebut, peramalan yang nilai kesalahannya terkecil adalah metode Exponential Smoothing dengan $\alpha=0,2$ dengan nilai MAPE atau rata-rata kesalahan persentase absolut terhadap permintaan aktual terkecil yakni 32,67; MAD atau rata-rata kesalahan mutlak terkecil (tanpa memperhatikan hasil peramalan lebih besar atau kecil jika dibandingkan dengan kenyaataan) yakni 286.023,31; MSE atau ratarata kesalahan kuadrat terkecil yakni 118.336.236.635,27; dan MFE atau rata-rata kesalahan peramalan terkecil yakni 286.023,31. Sehingga peramalan produk Atap $\mathrm{H}$ menggunakan Exponential Smoothing dengan $\alpha=0,2$. MAPE biasanya lebih berarti dibandingkan MAD karena MAPE menyatakan persentase kesalahan hasil peramalan terhadap permintaan aktual selama periode tertentu yang akan memberikan informasi persentase kesalahan teralu tinggi atau teralu rendah.

\section{Verifikasi Moving Range}

Verifikasi Moving Range Forecast periode selanjutnya dengan persamaan berikut:

$$
M R=\left|\left(d_{t}^{\prime}-d_{t}\right)-\left(d_{t-1}^{\prime}-d_{t-1}\right)\right|
$$

Hasil peramalan metode terbaik yaitu menggunakan metode peramalan Exponential Smoothing dengan $\alpha=0,2$, berikut adalah perhitungan hasil verifikasi dengan Moving Range, yaitu proses verifikasi yang dilakukan untuk mengetahui apakah fungsi peramalan yang ditentukan telah cukup representatif untuk data yang akan diramalkan, dapat dilihat pada tabel 8 .

Table 8 Moving Range

\begin{tabular}{|c|c|c|c|c|c|}
\hline Bulan & T & $\mathbf{d}$ & $\mathbf{d}^{\prime}$ & $\left|\mathbf{d}^{\prime}-\mathbf{d}\right|$ & MR \\
\hline Januari & 1 & 959.288 & - & - & - \\
\hline Februari & 2 & 848.601 & $191.857,60$ & $656.743,40$ & $302.544,6$ \\
\hline Maret & 3 & 922.392 & $323.206,28$ & $599.185,72$ & $57.557,68$ \\
\hline April & 4 & 885.497 & $443.043,42$ & $442.453,58$ & $156.732,14$ \\
\hline Mei & 5 & 885.497 & $531.534,14$ & $353.962,86$ & $88.490,72$ \\
\hline Juni & 6 & 701.018 & $602.326,71$ & $98.691,29$ & $255.271,57$ \\
\hline Juli & 7 & 959.288 & $622.064,97$ & $337.223,03$ & $238.531,74$ \\
\hline Agustus & 8 & 922.392 & $689.509,58$ & $232.882,42$ & $104.340,61$ \\
\hline September & 9 & 885.497 & $736.086,06$ & $149.410,94$ & $83.471,48$ \\
\hline Oktober & 10 & 996.184 & $765.968,25$ & $230.215,75$ & $80.804,81$ \\
\hline November & 11 & 996.184 & $812.011,40$ & $184.172,60$ & $46.043,15$ \\
\hline Desember & 12 & 996.184 & $848.845,92$ & $147.338,08$ & $36.834,52$ \\
\hline $\begin{array}{c}\text { Total } \\
\text { Jumlah }\end{array}$ & $\mathbf{7 8}$ & $\mathbf{1 0 . 9 5 8 . 0 2 2}$ & $\mathbf{6 . 5 6 6 . 4 5 4 , 3 2}$ & $\mathbf{3 4 3 . 2 2 7 9 , 6 8}$ & $\mathbf{1 . 4 5 0 . 6 2 3 , 0 0}$ \\
\hline
\end{tabular}

Rata-rata Moving Range dinotasikan dalam persamaan:

$$
\overline{M R}=\sum \frac{M R}{n-1}
$$

Dimana, $n$ merupakan jumlah bulan yang diramalkan.

$$
\begin{aligned}
& \overline{M R}=\frac{1.450 .623}{12-1} \\
& \overline{M R}=131.874,82
\end{aligned}
$$

Batas kontrol data dapat dicari dengan menggunakan persamaan dibawah ini:

$$
\begin{aligned}
& U C L=2,66 \times \overline{M R} \\
& U C L=2,66 \times 131.874,82 \\
& U C L=350.787,02 \\
& L C L=-2,66 \times \overline{M R} \\
& L C L=-2,66 \times 131.874,82 \\
& L C L=-350.787,02
\end{aligned}
$$

Berdasarkan perhitungan Batas kontol atas dan bawah serta moving range, maka data dapat di plot dalam grafik pada gambar 5 . Gambar 5 Metode ini diasumsikan cukup representatif dikarenakan bahwa keseluruhan data berada di dalam batas kendali sehingga fungsi peramalan metode Exponential Smoothing dengan $\alpha=0,1$ dapat digunakan.

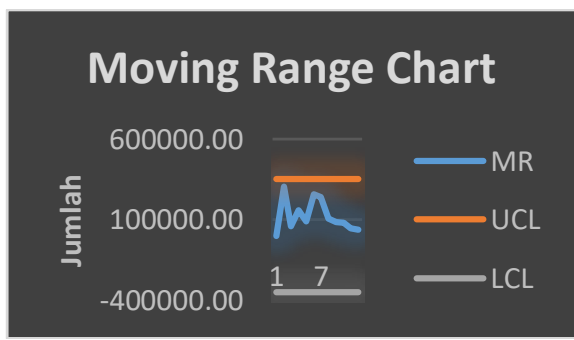

Gambar 5 Peta Moving Range 


\section{KESIMPULAN}

1. Berdasarkan data historis perusahaan, didapatkan grafik peramalan yang memiliki pola horizontal dikarenakan fluktuasi nilai berada disekitar rata-rata maka perhitungan peramalan permintaan beserta tingkat kesalahannya diketahui bahwa terdapat tiga metode yang digunakan yaitu; Metode Exponential, Exponential Smoothing dengan $\alpha=0,1$ dan Exponential Smoothing dengan $\alpha=0,2$.

2. Selanjutnya, metode peramalan yang tepat dapat ditentukan berdasarkan tingkat kesalahan yang paling terkecil dari ketiga metode berikut;

a. Metode Exponential yang mengasilkan mean absolute deviation (MAD) $8.848 .184,75$, mean square error (MSE) 98.322.462.316.708,30 , mean forecast error (MFE) 8.848.184,75, dan mean absolute percentage error (MAPE) 961 ;

b. Metode Exponential Smoothing dengan $\alpha=0,1$ yang mengasilkan mean absolute deviation (MAD) 474.088,67, mean square error (MSE) 263.754.545.864,38, mean forecast error (MFE) 474.088,67, dan mean absolute percentage error (MAPE) 52,52 ;

c. Metode Eksponensial Smoothing dengan $\alpha=0,2$ yang menghasilkan mean absolute deviation (MAD) 286.023,31, mean square error (MSE) 118.336.236.635,27, mean forecast error (MFE) 286.023,31, dan mean absolute percentage error (MAPE) 31,67 .

Sehingga Metode yang paling tepat digunakan dalam menganalisis data dengan memiliki tingkat kesalahan yang paling terkecil dari ketiga metode yang digunakan pada produk Atap H untuk ramalan Januari 2019 yaitu menggunakan Metode Exponential Smoothing dengan $\alpha=0,2$ dengan nilai MAPE atau rata-rata kesalahan persentase absolut terhadap permintaan aktual terkecilnya yakni 32,67; MAD atau rata-rata kesalahan mutlak terkecilnya (tanpa memperhatikan hasil peramalan lebih besar atau kecil jika dibandingkan dengan kenyaataan) yakni 286.023,31; MSE atau rata-rata kesalahan kuadrat terkecilnya yakni 118.336.236.635,27; dan MFE atau ratarata kesalahan peramalan terkecilnya yakni $286.023,31$. Sehingga peramalan produk Atap H untuk tahun 2019 dapat menggunakan Metode Exponential Smoothing dengan $\alpha=0,2$.

\section{DAFTAR PUSTAKA}

Heriansyah, E., \& Hasibuan, S. (2017). Implementasi Metode Peramalan pada Permintaan Bracket Side Stand K59a. Jurnal PASTI. Vol. XII (2), 209-223.

Kushartini, D., \& Almahdy, I. (2013). Sistem Persediaan Bahan Baku Produk Dispersant di Industri Kimia. Jurnal PASTI. Vol. X (2), 217-234.

Rosdiani, V. (2018). Evaluasi Metode Peramalan Permintaan dan Perencanaan Agregat Atap Harflex di PT. Bakrie Building Industries. Magister. Universitas Gajah Mada.

Seto, S., Nita, Y., \& Triana, L. (2016). Manajemen Farmasi : Lingkungan Apotek, Farmasi Rumah Sakit, Indutri Farmasi, Pedagang Besar Farmasi Diakses pada https://books.google.co.id

Sofyan, D.K. (2013). Perencanaan \& Pengendalian Produksi. Lhoksemawe NAD: Graha Ilmu.

Tampubolon, M.P. (2018). Manajemen Operasi \& Rantai Pemasok-Edisi Revisi. Jakarta: Mitra Wacana Media.

Zulhamidi., \& Hardianto, R. (2017). Peramalan Penjualan The Hijau dengan Metode ARIMA (Studi Kasus pada PT. $M K)$. Jurnal PASTI. Vol. XI (3), 231244. 